\title{
Editorial \\ Advances in Food Processing (Food Preservation, Food Safety, Quality and Manufacturing Processes)
}

\author{
Theodoros Varzakas ${ }^{1, *}$ and Panagiotis Tsarouhas ${ }^{2, *}$ \\ 1 Department of Food Science and Technology, University of Peloponnese, Antikalamos, \\ 24100 Kalamata, Greece \\ 2 Department of Supply Chain Management (Logistics), International Hellenic University, Kanellopoulou 2, \\ 60100 Katerini, Greece \\ * Correspondence: theovarzakas@yahoo.gr (T.V.); ptsarouhas@ihu.gr (P.T.)
}

check for updates

Citation: Varzakas, T.; Tsarouhas, P. Advances in Food Processing (Food Preservation, Food Safety, Quality and Manufacturing Processes). Appl. Sci. 2021, 11, 5417. https://doi.org/ 10.3390/app11125417

Received: 31 May 2021

Accepted: 10 June 2021

Published: 10 June 2021

Publisher's Note: MDPI stays neutral with regard to jurisdictional claims in published maps and institutional affiliations.

Copyright: (c) 2021 by the authors. Licensee MDPI, Basel, Switzerland. This article is an open access article distributed under the terms and conditions of the Creative Commons Attribution (CC BY) license (https:/ / creativecommons.org/licenses/by/ $4.0 /)$.
The aim of this special issue was to bring about advances in the area of food manufacturing, including packaging, addressing issues of food safety, quality, fraud and how these processes (new and old) could affect the organoleptic characteristics of foods, with the aim of promoting consumer satisfaction. Moreover, food supply issues have also been explored.

In this direction, packaging is the last step in the manufacturing process and makes the product attractive. In addition, it can extend the shelf life of the product. Hence, edible coatings have been used extensively. Acevedo-Correa et al. [1] report on the effect on cassava chips of coatings consisting of pectin and whey protein films. The coating type affected all sensory parameters except crispness, and temperature only influenced the color of the control chips.

Ishkeh et al. [2] employed chitosan as an edible coating to increase the storage of raspberries, and nanoparticles of chitosan were used to increase chitosan efficiency. This methodology was considered effective, safe and environmentally friendly, with healthpromoting effects.

In regard to the development of new technologies and the advancement of existing technologies, Negara et al. [3] developed high-frequency defrosting, superheated steam and quick-freezing treatments to improve the quality of seafood home meal replacement products. They examined the chemical, microbiological and organoleptic properties of the products and saw no statistical changes over 90 days. The optimal temperature and heating time for this technology were also determined.

Rana et al. [4] also employed superheated steam roasting $\left(270^{\circ} \mathrm{C}\right.$ for $\left.4 \mathrm{~min}\right)$ and hot smoking $\left(70^{\circ} \mathrm{C}\right)$ of chub mackerel fillets to extend their shelf-life at the market level. Oak sawdust for 25 min of smoking time offered the best organoleptic characteristics, along with the optimal physiochemical and microbiological parameters.

Ultrasonic pretreatment was employed in the work of Taghinezhad et al. [5] for drying kiwi fruits under hybrid hot air-infrared conditions. The effective moisture diffusivity coefficient (Deff) was estimated, along with other parameters, and different models were used. The results revealed the effect of temperature and ultrasonic pretreatment time, along with sample thickness, on these parameters.

The study by Liu et al. [6] enabled calcium alginate ball encapsulation in fruit-flavored drinks (Boba milk tea made of tapioca). This technology showed that the organoleptic control and microbiological quality of the products were not affected if the product was stored at a temperature less than $10^{\circ} \mathrm{C}$.

Diaz-Bustamante et al. [7] contributed to the design of costeño-type artisan cheeses with specific functionalities through multiscale modeling by means of the substitution and reduction of $\mathrm{NaCl}$ and an increase in cooking temperature. The microstructure was not affected by the reduction in salt or by modifications in the cheese-making process.

The next two studies, which were carried out in Greece, investigated safety and quality aspects. Voidarou et al. [8] screened raw unprocessed honeycombs filled with oregano 
honey from Epirus, Greece, for bacteriocinogenic lactic acid bacteria and Bifidobacterium spp. exerting inhibitory action towards some pathogens and spoilage microorganisms isolated from fresh fruits and vegetables. The results suggested that bacteriocin-like substances are involved in this process.

Skiada et al. [9] evaluated and discriminated between monovarietal extra virgin olive oils obtained from olive cultivars cv. Lianolia Kerkyras and cv. Koroneiki, produced in Greece, based on their chemical characteristics, followed by statistical and chemometric analysis. They showed that possible authenticity tools could include sterol and fatty acid composition markers.

The work of Agustinisari et al. [10] deals with research and development, and more specifically with the formulation of protein and polysaccharides (whey proteinmaltodextrin) in eugenol encapsulation and the determination of the effect of eugenol and chitosan concentrations on the characteristics of emulsions and spray-dried powders. The presence of chitosan resulted in more stable emulsions.

The next study, by Cucci et al. [11], reports on a new methodology for the rapid measurement of the redox potential as an indicator of color changes for meat juice in carcasses without slowing down the slaughter line to avoid food waste. A symmetry was highlighted between these two parameters.

Food fraud is very frequent nowadays and could become very complex. However, analytical tools have been employed to address this phenomenon. MALDI-TOF MS has been used in different matrices and has a lot of advantages; hence, a review by Zambonin [12] demonstrates all the existing applications for the detection of food fraud.

Supply chain management needs to take into account issues of corporate social responsibility. A case study was employed here, representing the dairy sector in Vietnam. The study shows the close relationship between the company and consumers, which is reflected in its financial performance [13].

$\mathrm{Xu}$ et al. [14] proposed an advanced online-to-offline (O2O) strategy for a singlevendor single-retailer integrated system with coordination mechanisms consisting of revenue-sharing, buy-back and quantity flexibility.

This special issue has shown that new and improved technologies have been employed in the area of food manufacturing, addressing consumer needs in terms of quality and safety. The issues of research and development should be taken into account before launching a new product into the market. Finally, food fraud and authenticity are very important issues and the food industry should focus on these.

Conflicts of Interest: The authors declare no conflict of interest.

\section{References}

1. Acevedo-Correa, D.; Jaimes-Morales, J.; Montero-Castillo, P. The Effect of Edible Coatings on Selected Physicochemical Properties of Cassava Chips. Appl. Sci. 2021, 11, 3265. [CrossRef]

2. Ishkeh, S.; Shirzad, H.; Asghari, M.; Alirezalu, A.; Pateiro, M.; Lorenzo, J. Effect of Chitosan Nanoemulsion on Enhancing the Phytochemical Contents, Health-Promoting Components, and Shelf Life of Raspberry (Rubus sanctus Schreber). Appl. Sci. 2021, 11, 2224. [CrossRef]

3. Negara, B.; Kim, S.; Sohn, J.; Kim, J.-S.; Choi, J.-S. Application of High-Frequency Defrosting, Superheated Steam, and QuickFreezing Treatments to Improve the Quality of Seafood Home Meal Replacement Products Consisting of the Adductor Muscle of Pen Shells and Common Squid Meat. Appl. Sci. 2021, 11, 2926. [CrossRef]

4. Rana, M.; Mohibbullah, M.; Won, N.; Baten, A.; Sohn, J.; Kim, J.-S.; Choi, J.-S. Improved Hot Smoke Processing of Chub Mackerel (Scomber japonicus) Promotes Sensorial, Physicochemical and Microbiological Characteristics. Appl. Sci. 2021, 11, 2629. [CrossRef]

5. Taghinezhad, E.; Kaveh, M.; Szumny, A. Thermodynamic and Quality Performance Studies for Drying Kiwi in Hybrid Hot Air-Infrared Drying with Ultrasound Pretreatment. Appl. Sci. 2021, 11, 1297. [CrossRef]

6. Liu, Y.; Cheng, H.; Wu, D. Preparation of the Orange Flavoured “Boba” Ball in Milk Tea and Its Shelf-Life. Appl. Sci. 2020, 11, 200. [CrossRef]

7. Diaz-Bustamante, M.L.; Reyes, L.H.; Solano, O.A.A. Application of a Multiscale Approach in the Substitution and Reduction of $\mathrm{NaCl}$ in Costeño-Type Artisan Cheese. Appl. Sci. 2020, 10, 9008. [CrossRef] 
8. Voidarou, C.; Alexopoulos, A.; Tsinas, A.; Rozos, G.; Tzora, A.; Skoufos, I.; Varzakas, T.; Bezirtzoglou, E. Effectiveness of Bacteriocin-Producing Lactic Acid Bacteria and Bifidobacterium Isolated from Honeycombs against Spoilage Microorganisms and Pathogens Isolated from Fruits and Vegetables. Appl. Sci. 2020, 10, 7309. [CrossRef]

9. Skiada, V.; Agriopoulou, S.; Tsarouhas, P.; Katsaris, P.; Stamatelopoulou, E.; Varzakas, T. Evaluation and Origin Discrimination of Two Monocultivar Extra Virgin Olive Oils, Cultivated in the Coastline Part of North-Western Greece. Appl. Sci. 2020, 10, 6733. [CrossRef]

10. Agustinisari, I.; Mulia, K.; Nasikin, M. The Effect of Eugenol and Chitosan Concentration on the Encapsulation of Eugenol Using Whey Protein-Maltodextrin Conjugates. Appl. Sci. 2020, 10, 3205. [CrossRef]

11. Cucci, P.; N'Gatta, A.C.K.; Sanguansuk, S.; Lebert, A.; Audonnet, F. Relationship between Color and Redox Potential (Eh) in Beef Meat Juice. Validation on Beef Meat. Appl. Sci. 2020, 10, 3164. [CrossRef]

12. Zambonin, C. MALDI-TOF Mass Spectrometry Applications for Food Fraud Detection. Appl. Sci. 2021, 11, 3374. [CrossRef]

13. Chen, T.-S.; Huang, Y.-F.; Weng, M.-W.; Do, M.-H. Two-Stage Production System Pondering upon Corporate Social Responsibility in Food Supply Chain: A Case Study. Appl. Sci. 2021, 11, 1088. [CrossRef]

14. Xu, N.; Huang, Y.-F.; Weng, M.-W.; Do, M.-H. New Retailing Problem for an Integrated Food Supply Chain in the Baking Industry. Appl. Sci. 2021, 11, 946. [CrossRef] 